\title{
Electoral Politics: A Case Study of Pakistan
}

\section{(1947-1985)}

\author{
Muhammad Ibrahim \\ Lecturer in Political Science at Government Postgraduate College Bahawal Nagar \\ Email: prof.ibrahim69@yahoo.com
}

Professor Dr. Razia Mussarat

Chairperson, Department of Political Science, The Islamia University of Bahawalpur

Accepted: December 31, 2014

Doi:10.5296/ jpag.v5i1.7083 URL: http://dx.doi.org/10.5296/ jpag.v5i1.7083

\begin{abstract}
Electoral politics effects democracy and political system. Elections are essential component of modern democracy. The authoritarian pattern of government is harmful for institutional development process. The constitutional and institutional developmental process is weak in Pakistan. The federal system government is not work in Pakistan in true sense. These issues weakened political system of Pakistan. The institutions may get proper development to strengthen democratic system. The political structures and governing experience is not matched to democratic world. The power politics contributed to inability of parliamentary democracy to govern new country effectively. Democracy remained poor in Pakistan. Military rulers governed in Pakistan more than half of time. The assumption is that democracy is controlled by the electoral process. The paper covers electoral politics of Pakistan from 1947 to 1985.
\end{abstract}

Keywords: Democracy, electoral politics, military rule, Basic Democracy System and Referendum 


\section{Introduction}

In Pakistan with such an encouraging start Muslim League could confidently look forward to a long untroubled spell to a rule of law. It was continuously in power in all provinces and center. Pakistan Muslim League had domination of power in governing system. It had power in the legislative and ministerial spheres. It had influence in provincial government and high diplomatic fields. It had un-challenged right of appointment to all ambassadorial posts and majority in the Constituent Assembly. There was no general election held to test the popularity. The adverse effects of electoral politics were felt in Pakistan. Since 1947 to 1958, there was no proper institution to hold direct elections in Pakistan at the national level. Different Provincial Assemblies elections were held at different time. The West Pakistan Assembly' selections were described as a pretense, ridicule and a fraud. Elections are having key of the democratic system. There were no general elections held on the principles of the modern world. Unluckily this continuity was existed for long period in Pakistan. Ahmed Rashid argues military-bureaucratic elite steered Pakistan's fortune from day of independence. It assumed right to define nature of menace to national security. The solutions were decided by military-bureaucratic elite and not by elected governments, parliament, civic organizations or even common sense.(Rashid, 2001)

After independence the controlled democracy by electoral politics started in Pakistan. After independence, Pakistan adopted Indian Act of 1935 as an interim constitution of Pakistan. Pakistan finally adopted the constitution in 1956after long struggle of several failure attempts. This constitution was not permitted to work for a long time and before the general elections General Muhammad Ayub took over the government in October 1958. It may be said that free and fair elections are essential of democratic process. (Ghaur, Ayub Khan: Pakistan's First Military Rule, 1994)

\section{Electoral Process}

After independence, first direct elections were held for provincial Assembly of Punjab from 10 to 20Marchin 1951. There were 197 seats in Punjab Provincial Assembly. 939 candidates participated in the election for 189 seats, other nine were elected unopposed. Different political parties were in contesting elections. There were nearly one-million voters. The elections were contested on an adult franchise basis. The turnout of election remained low. The people participation in voting process in city areas of Lahore was 30 per cent and it was considerably poorer in country areas of Punjab.(A.V.Vorys, 1956)

In North West Frontier Province elections were held on 8 December 1951 for Provincial Assembly. As it was trend set in provincial Assembly election to blame winner candidates riggings. Likewise controversies were in Sindh Provincial Assembly elections which were held in May, 1953.(Kalam, 1959)The elections for East Pakistan Assembly were held in April 1954.Pakistan Muslim League lost these elections in East Pakistan and alliance won which consisted of Bengali nationalists. Before independence general elections held in subcontinent on the principle of separate electorate. Muslim League won the Muslim seats with majority. The total strength of Constituent Assembly was 69 in 1947. The number had grown to 79 on the account of representation given to the refugees, the States and Tribal Areas in 
1954.(K.K.Aziz, 1976) The new members were nominated. It is made by the nomination process for the constituent assembly. Its first function was to frame the constitution for newly born state which had two wings, five provinces and sixteen stateswhich made affiliation with Pakistan. Different languages were spoken in different region and different regional identities were creating problems. All these factors were kept in the view in the process of constitution making. These institutional imbalances impeded the development of democratic institutions. First Constituent Assembly tried to curtailpowers the powers of Governor General. There were efforts to introduce a bill amending Section 10 of the Government India Act 1935 under which Governor General could dismiss the Prime Minister. Governor-General Ghulam Muhammad dissolved the constituent assembly on October24, 1954. (Khan, Constitutional and Political History of Pakistan, 2001) Second Constituent Assembly was induced. Italso followedschedule established by Governor-General. There was need of decentralized system having legislature-dominated system. But presidential form of government emerged.(Charles, 2005). Constituent Assembly was elected indirectly. There were no proper institutions to conduct election. Neither it was thought about to conduct direct election for public representation. From the day of independence, it was started the controlled politics with the help of controlled election. The controlled democratic governments established with the help of controlled electoral process. That was

practiced in Pakistan since Independence Day. After this election the party position in the Constituent Assembly was as follows,

Table No 1

Representation of Political Partiesin First Legislative Assembly

\begin{tabular}{|c|c|c|}
\hline Position of Party & $\mathbf{1 9 4 7}$ & $\mathbf{1 9 5 3}$ \\
\hline Congress & 16 & 11 \\
\hline Miscellaneous & 04 & 03 \\
\hline Pakistan Muslim League & 49 & 60 \\
\hline Vacant & - & 05 \\
\hline Total & 69 & 79 \\
\hline
\end{tabular}

Source:(Ahmad M. , Politics and Government, 1959 p.89)

The refugees, FATA and states were givenrepresentation which increased the strength of Constituent Assembly. This representation enhanced the strength of Muslim Leagues in constituent assembly. Political corruption was rising which proved after that in power game for establishment for government. Representation of federal units in the Constituent 
Assembly was as follow as;

Table No 2

First Constituent Assembly of Pakistan (1947-54)

\begin{tabular}{|l|ll|}
\hline \multicolumn{1}{|c|}{ Areas } & \multicolumn{2}{|c|}{ Seats } \\
\hline Punjab & 22 & \\
\hline Sindh & 05 & 44 \\
\hline East Pakistan & & 01 \\
\hline Baluchistan & 01 \\
\hline Baluchistan States & 01 \\
\hline Bahawalpur & 01 \\
\hline Khairpur & 03 \\
\hline N.W.F.P & & 01 \\
\hline N.W.F.P States & & 019 \\
\hline Total & & 01 \\
\hline
\end{tabular}

Source: (Ahmad M. , Politics and Government, 1959 p.89)

Although Muslim League had majority in the Constituent Assembly but no prominent leaders after the assassination of Liaquat Ali Khan who had a strong grip on the party for discipline for the governmental structure. The weak leadership had no control over the party so it became the house maiden of civil and military bureaucracy. The most conspicuous feature of Pakistan's party politics was a lack of discipline, loyalty and sense of responsibility. Due to which in short period Muslim League was defeated in Bengal in provincial election of 1954. This was the period which should have to provide the guide map for all aspects of life in the state. The Governor General of Pakistan involved itself in politics of Pakistan, he became the King maker of the government which was against the democratic norms. In this way Pakistani politics was control by a single man.

\section{East Pakistan Elections1954}

Provincial Assembly elections were held in 1954 in East Pakistan from March 8 to 11, 1954. The political parties made an allianceUnited Front to oppose ruling party, which consisted of Awami Muslim League, Krishak-Sramik Party and Nizam-i-Islam parties. Party program of 
United Front was as under.

1. To recognize Bengalilanguage as an official language with Urdu.

2. To reject draft of constitution, and dissolve Constituent Assembly, which is replaced by direct elected Assembly.

3. Demand for complete autonomy for East wing except foreign policy and currency which reserved for the central legislature.

4. It was demanded about export of jute with consent of provincial government.

5. Allocation of foreign exchange.(Keesing, 1973)

These elections were won by opposition parties. The vote casting rate was high as $65 \%$ in provincial elections of Bengal.Five ministers of the running government lost their seats. The United Front won 223 seats having Awami Muslim League 143,Krishak-Sramik Party 48, Nezam-i-Islam19,Ganatantri Dal 13, Muslim League 9 and Independent 5. (A.V.Vorys, 1956)

Bengali United Front demanded resignation of the central government. United Front further demanded to dissolve the Constitution Assembly which was now unrepresentative. Prime Minister of Pakistan Chaudary Muhammad Ali rejected the demand saying as, it was responsibility ofall members of Constituent Assembly whether Muslims or non-Muslims. The specific objective was to make constitution.According to him, Constituent Assembly had to resignin case of any party's defeat in provincial assembly election was not justified. There was possibility of elections of different provincial assemblies in short period, and then character of government changed with new party position would not provide stability. The members of Constituent Assembly of Muslim League from Bengal were refused toresign. But when this Constituent Assembly curtailed powers of Governor General, he dissolvedConstituent Assembly on 24 October 1954. (Hamid, 2001 Pp 136-143)It was declared by Governor General an end to what he defined as parliamentary squabbling. (G.W.Chaudary, 1969 p.67)The state of emergency was declared throughout country. It was decided in light of political crisis which was becoming serious. The Constituent Assembly lost confidence of masses of state. It would no longer be functional against public aspiration. The dissolution was justified by East Pakistan. It was not democratic principle. It was near to end its work for the constitutional making. Mr. Ghulam Muhammad asked to Muhammad Ali Bogra Prime Minister to form a cabinet. Cabinet was consisted of Major General IskanderMirza, Dr Khan Shaib and General Ayub Khan who was Commander-in- Chief of Pakistan Army. It was start of participation of Pakistan Army in power of politics of state. It was declined supremacy of civilian over military. Such decisions lead to undemocratic rule in Pakistan. Military and bureaucracy annex has been started in power game of state.(Chaudhary, 1963)

\section{Second Constituent Assembly of Pakistan 1955}

Supreme Court of Pakistan decided infavour of Governor General of Pakistan with reference to dissolution of Constituent Assembly.It cleared the summoning of second Constituent Assembly onApril 13, 1955. Two days later, Governor General by proclamation summoned 
the convention of Constituent Assembly on May 10, 1955. (Qadeer Din Ahmad)Theconvention was held to elect members from existing Provincial Assemblies. Its function was to replace the first constituent Assembly. Governor General appointed a person to preside over session of convention. The leaders of United Front threatened to boycott the convention. The formation of Constituent Assembly was not on the base of population. United Front and Government made deal to restore the suspended Assembly of East Pakistan. United Front agreed to accept equivalence of representation. The leader and Law Minister Mr. Suhrawardyof Awami League was also putative it.(Ahmad M. , 1959 p.106)

Representation of different states and provinces of Pakistan in Constituent Assembly was as follow,

Table No 3

2nd Constituent Assembly of Pakistan (1955-58)

\begin{tabular}{|c|c|}
\hline Areas & Seats \\
\hline Punjab & 21 \\
\hline Sindh & 05 \\
\hline East Pakistan & 40 \\
\hline N.W.F.P & 04 \\
\hline Baluchistan & 01 \\
\hline Bahawalpur & 02 \\
\hline Khairpur & 01 \\
\hline N.W.F.P States & 01 \\
\hline Karachi & 01 \\
\hline Tribal Areas & 03 \\
\hline Total & 80 \\
\hline
\end{tabular}

Source: (Ahmad M. , 1959 p.106)

The convention was held on the principle of parity for representation of both wings of Pakistan.Party position in Constituent Assembly was as follow, 
Table No 4

Second Constituent Assembly Party wise Position (1955-58)

\begin{tabular}{|c|c|c|}
\hline Party's Name & 1955 & October 1958 \\
\hline Muslim League & 33 & 15 \\
\hline Republican & - & 21 \\
\hline United Front & 16 & - \\
\hline Awami League & 13 & 13 \\
\hline KrishokShaarmik & - & 16 \\
\hline National Awami Party & - & 04 \\
\hline Noon Group & 03 & - \\
\hline Nizam-e-Islam & - & 03 \\
\hline Congress & 04 & 04 \\
\hline Scheduled Cast Federation & 03 & 02 \\
\hline United Progressive Party & 02 & 01 \\
\hline Independents & 06 & 09 \\
\hline Vacant & - & 02 \\
\hline
\end{tabular}


Total

80

80

Source; (Ahmad M. , 1959 p.106)

After convention of Constituent Assembly the results showed party position. There was no single party in position to formulate the federal government in Pakistan. It was time to established coalition government. The coalition government experience was not giving fruitful results.

\section{The Ayub Regime 1958-69}

After the imposing martial law, the state power came in the hands of General Ayub Khan. IskanderMirzahad been appointed General Ayub khan asChief Martial Law Administer. There was started power struggle between two personalities. Army Chief Mr. Muhammad Ayub Khan decided to gain the state power on October 27, 1958.Then President IskanderMirza sent exile to Great Britain. (Bukhari, 1964)

\section{Basic Democracies System}

Chief Martial Law Administer Muhammad Ayub Khan presentedcompletepattern of local self-government.Basic Democracies Order1959 implemented on October 27, 1959. It was plane to control politics by some selected members. It may be a good system if it was implemented with the sincerity and transfer of power to the grass root level. The concept of Basic Democracies was adopted after study of different countries. Some countries made implications of this system. There were situation may be different with other factors. Each country had its own environment and requirements. Pakistan had own requirements of our own nation and theprodigy of peoples.(Gopal, 1959)

The role of Basic Democracies may be linked to the local democratic institutions. But the role was spread to constitute the electoral college of President of Pakistan. It was felt that people were not genius to elect the representatives and the President. The conditions of western democracy were not suitable. Larger population denied to directly elect and vote for President of Pakistan, lacking any trust in Ayub Khan, argued that electors could be bribed, brought and paid for and their role easily be compromised. Ayub khan claimed to find the necessary techniques for the justification of ideas as Basic Democracies. Ayub Khan implored his countrymen to vote for the best representatives and by 23 January 1960 the 80,000 Basic Democrats had been chosen.(Feldman H. , A Constitution for Pakistan, 1975)

\section{Presidential Elections}

The indirect elections were introduced under Constitution 1962, not only for Presidential election but also for National and Provincial Assemblies. The function of Basic Democrats 
was local self-government. But the Democrats became the elector of the both Provinces. After five years this Electoral College will dissolve but the functions about the performance of local government. The age limit for member of Electoral College was 25 years. The President of Pakistan issued an (order No3) for the election process was done by the secret ballot paper. The voters were asked to showconfidence on Ayub khan. The majority of voters of Basic Democratic decided about President of Pakistan. Election was held on 14 February 1960. There was no other choice for the voter so the casted their votes in favor of the Candidate of the President. General Ayub Khan got 75283 votes of the Electoral College which is $96.5 \%$ of the total Electoral College. In this way President of Pakistan was not only elected but got mandate for constitutional development of own choice. In Pakistan under the Constitution of 1962 presidential form of government was introduced. President had powers of state and become a dictator. President had power to dissolve Assembly, appointment and termination of ministers. Presidential form of Government was not justified with special reference to the East Pakistan under indirect election. It was persuadedabout presidential arrangement of government thatsecure integrity and unity of state. There could be no tempering with future of constitution. It was realizedPresident'spowerswill ensure to solve issues of Pakistan.(G.W.Chaudary, 1969 p.67)

Ayub Khan banned political parties. The political leaders were disqualified banned under EBDO.The efforts were made to convince people of Pakistan that country was being healthier without political parties. Some parties as National Awami Party (NAP), Muslim League, Jamaat-e-Islami, Awami League were functioning with impunity outsidethe assembly. Ayub Khan strengthened his government. There was no fear to subversion of government.There was political vacuum in politics without political parties. It was feeling toregulate political partiesfor controlled functioning. Under political aspiration a bill was introduced to permit political activities in July 1962. President signed it on 16th of July that developsregulation. Notwithstanding some problematic provisions as government's aptitude to take actionsagainst those have affianced in activities painstaking unfavorable to health and security of nation. Thepolitical parties were dynamic inside and outside legislature. Ayub Khan had not pulverized words in condescension for structured political parties. It was accredited and forced to accept the reestablishment of political parties.After that, it was made a fanaticalappeal to nation on July 20thfor national level political party. This party has capability to amalgamate the nation. Its basic function was to direct its energies towards national reconstruction. To follow up appeal, Ayub and his fellows started to set up a Ruling Party. Its basic function was representationof government in and outside of legislature. This party named as Convention League which made request Ayub Khan to undertake presidency of party on December 15, 1962. Our national leaders Quaid-e-Azam and Liaquat Ali Khan had kept president ship of party while holdingofficial responsibility of state. Ayub Khan joined the Convention League in May of 1963 and assumed its presidency seven months later.(Ghaur, 1993)

Ayub Khan had started planning for next coming presidential election. The debate was continued about the matter of direct or indirect electoral process. At this pressure a commission had appointed to cautious over issue of indirect or direct election. The 
commission studied about matter and prepareda final report to submitin February 1963. The commission was having two members with a chairman. The majority of members were in favor of direct electionon basis ofadult franchise. The report was major mortification for President. The government was in problematic situation and in search of safe passage to escape from situation. To solve and maintain control over electoral process a special committee was articulated underMinistry of Law to overruleFranchise Commission's report. To defend present report government used officials to propagate in favor of universal suffrage.Governor of east wingwas asserting citizens had used maximum suffrage in electoral process. It was argued that each citizen had opportunity to vote for selection of basic democrat. These members were electing members of national and provincial assemblies.(Hamid, Constitutional and apolitical History of Pakistan, , 2006)

\section{Presidential Elections 1965}

According to constitution of 1962 next President Election must be held 120 days before the expiry of tenure of President. Presidential Election was announced to conduct on January 2, 1965. Ayub Khan was Presidential candidate of Convention Muslim League. He was becoming president of party on the 24 December 1963. National Assembly opposition partiesjoined together to oust President Ayub Khan from power. Therefore Combined Opposition Parties (COP) formed which consisted of Council Muslim League, Awami League, and National Awami Party. (Herlad, 2002) Miss Fatima Jinnahhad not participated in politics after Quid-i-Azam death.She made a tour to East Pakistan in 1954. Now opposition invited Miss Fatima Jinnah as Presidential candidate against Muhammad Ayub Khan in the elections of 1965. Miss Fatima willingly ready to oppose Presidential candidate General Ayub Khan and returned to forefront of political life in Presidential Election of Pakistan. As opposition candidate addressed gatherings and rallies, shebecame symbolized about democratic aspirations of people. Fatima Jinnah decided to contest elections as Presidential candidatein 1965 which changed electoral landscape. The inexorable and unbeaten Ayub Khan was challenging in electoral process. The procedure ofindirect election had instituted by him. Presidential candidates were announced for elections of 1965 formerly origination of Basic Democracy elections. These Basic Democracy elections constituted Electoral College for Presidential and Assembly elections. Convention Muslim League and Combined Opposition Partieswas two contester of election. Combined opposition parties declared manifesto which comprised for reinstatement direct general elections, adult franchise and development of constitutionaccording to democratic aspiration.(Ahmad K. , May 23, 1998) The combined opposition parties were not amalgamated. These parties had not infatuatedcommon political thought. It was difficult to act jointly. That was reality parties were having theirown candidates forpresidential election. These factors were forcing to nominate a high esteem personality as Fatima Jinnah for presidential election of January 2, 1965. Four presidential candidates were Ayub Khan, Fatima Jinnah and two others persons having no party affiliation. The election campaign period was short to one month. There were further restrictions to projection meetings. Election Commission organized meetings of presidential candidates withsuccessful members of Basic Democrats of Electoral College. The members of the press were also invited by 
election commission. Fatima Jinnah's imagewould have enhanced but people werestriatedto attend theseconventions.(Herbert, 1972)

Ayub Khan had an advantage over Fatima. He was armed with second Constitutional Amendment which confirmedas next coming as a new President. He exercised power over administrativeofficials during electoral process. He was as Head of State and enjoyed all facilities for support in election. These facilities did not get as president of his party or as candidate of presidential election. He did notfluctuateto legislate on electoral concerns. The bureaucracy and business were legatees from Ayub Khan Regime. In reward both were facilitated in election. He brought disgruntled elements backing him. To get support of students Ayub Khan assured to revise university ordinance. There was assurance for journalists the scrutiny of the Press Laws. There were ulema having opinion against women rule. It was said inIslamic process of government a woman has not act as head of state in Pakistan.Ayub Khan also gathered such ulema for support. Ayub Khan collected funds from businessmen. The appeal made for the success of respective candidate in the press. There were no public issues discussed in the election campaign but some specific issues were under debate. On the side of General Ayub Khan personality image was present in election campaign. There was made criticize on issue of Indus Water dispute with India. Ayub Khancapitulated river's control of rivers to India, the indirect election of President, Presidential form of the constitution which gave the uncontrolled and unlimited power to President of Pakistan made it the unification of power. On January 2, 1965 elections were held and next day results were announced. Ayub Khan gained 49951 Basic Democrats votes against Ms. Jinnah's 28691. Ms. Fatima subjugated Ayub Khan in Dhaka, Chittagong, and Karachi divisions. Election results were not accepted by combined opposition parties. Ms. Fatima Jinnah accused elections have been engineered. She further statedostensiblesuccess of Mr. Ayub Khan was his ultimate defeat. The elections results considered disputed which depreciation legitimacy of government of Ayub Khan. With the use of electoral political tactics General Muhammad Ayub Khan was elected as the president of Pakistan. (Khan, 2006) Such pattern decisions leaded to controlled pattern of government that was established under controlled electoral politics.

\section{General Elections 1970}

General Muhammad YahyaKhan announced on March 30, 1970 that LFO gazette on lay down elementary principle for future Constitution of Pakistan. One Unit will be dissolved on the $1^{\text {st }}$ July 1970 in Western Pakistan. National Assembly will comprise of 313 members in which thirteen seats earmarked for women. The polling will be held till 22 October 1970. The foremost objective was peaceful power transfer to the people.

There were no general elections held in Pakistan for federal government on the principle of adult franchise. There was not only need of general elections but also permanent machinery for election process. Election Commission was set up having three members, Justice AbdusSattar was appointed Chief Election Commissioner.The primary objective of Election Commission was to enroll the voter of age 21 years on October 1969. Voter lists for public to check for informationtill January 16, 1970 and published on March 17, 
1970. Total voters were 56941500 in which from Eastern wing 31211220 and from Western Wing 25730280 registered for casting votes.The election Commissioner marked constituencies, allocatednumber of National and Provincial Assemblies seats with accordance LFO 1970. 191 Returning officers for federal Assembly and 285 Returning Officers for Provincial Assemblies were appointed. (Dominque, 1975)Parties participated in election weretwenty four. Newly established Pakistan Peoples Party is gaining the popularity in West Pakistan on the slogan of the "Rotti, KapraAurMakan."Different parties adopted different slogan for the elections. Some parties rejected the LFO. But over all parties are welcomed the military decision for holding elections in Pakistan. Sheikh Mujeeb-ur-Rehman issued Awami Party manifesto based on the Six Points Zulfikar Ali Bhutto launched the manifesto on the economic disparities in the masses of Pakistan and 1000 years wars with India.Z.A Bhutto exploited the economic issue in West Pakistan cleverly and unrealistic promise of RottiKapraAurMukan which was appealing to public.(Bhutto, 1971)

First general elections were held in country in 1970. These elections were held on base of direct adult franchisewithout interference of governmentunder General Yahya Khan's rule. The elections were free and fair. Awami League party got majority in East Pakistan, Peoples Party in West Pakistan which leadsto political calamity in Pakistan. Indian military intervention started and Pakistani government used military force to settle down the issue in 1971.

Election Commission issued voting calendar for federal assembly held at October 5 and for provincial assemblies at October 19. The dates of polling were changed to December 7 and 17 due to floods in East Pakistan. The election for nine National Assembly and eighteen seats for provincial assembly were not held on fix timetable. The elections of these seats were conducted at January 17 of next year. There was reason sea hurricane knockout most areas of east wing of Pakistan.

The strength of contesting candidates was 1957 which submitted papers for 300 National Assembly seats. 1579 candidates survived after inspection and withdrawing process of election. There was no one party which have strengths of candidate to submit papers throughout the country for all seats. Awami League has strength of election candidates one hundred seventy and 162 were contesting in east wing. The second largest party was Jamaat-i-Islami whose 151 candidates filed papers in election. The newly established Pakistan People's Party could nominate only one hundred and twenty to contestfrom which one hundred and three were in Punjab and Sindh. Pakistan People's Party had no strength in East Pakistan for election. Convention Muslim League nominated 124 candidates, Council Muslim League 119 and Qayyum Muslim League 133. (Feldman H. , 1975)

According to results of Awami League got 160 seats of National Assembly. It becamesingle largest party. It easily won 288 seats in East Pakistan Assemblyout of 300 seats. The party failed to get seats for representation in west wing. PPP had managed to win 81 seats from 138 seats.PPP was newly established party that had well performance in polls of west wing major provinces of Punjab and Sindh assemblies. (Ziring, 1997)

The results publicizedright wing political parties in voters. There was division of votes 
among several candidates. There were many other parties as Muslim League(Qayyum), Muslim League (Council), Muslim League(Conventional), Jamiyat-i-Ulema-i-Islam, Jamiyat-i-Ulema-i-Pakistan and Jamaat-i-Islami securedon thirty seven seats of National Assembly. NAP (National Awami Party) and JUI (Jamiyat-i-Ulema-i-Islam) became prominent parties in North West Frontier Province and Baluchistan Assemblies.(Feldman H. , The End and The Begining: Pakistan 1969-1971, 1975)

\section{General Elections of 1977}

In September 1976,ZulfiqarAli Bhutto mapped out program of election campaign. Pakistan National Alliance centered their campaign on Bhutto's rule and concentrated initial attack on Karachi where Muhajirs community had reason to reject policies of Zulfiqar Ali Bhutto. Approximately 17 million of 31 million eligible voters were casted their ballots on March7, 1977 in general election. P.P.P no surprisingly got 105 seats out of 115 seats of National Assembly.Zulfikar Ali Bhutto was head of government.Thecivilian government conductedelections in March-April 1977. A joint opposition of nine political parties Pakistan National Alliance was launched a nation-wide protest on rigging charges on election. (Mujahid, 1980)

Pakistan National Alliance was formulated against undemocratic rule of Zulfikar Ali Bhutto. PNA socialize the masses at large scale for Islamic political system as M.G. Weinbaum wrote in his report Election 1977 that how after election PNA converted in an Islamic Public Movement and cause for change of Bhutto's government. (Weinlaum, July 1977)Meanwhile Prime Minister Zulifikar Ali Bhutto chose Zia-ul-Haq as Chief of Army staffon April 1, 1976,although he was junior officer. Zia-ul-Haqpersuadedhis eligibility for locus of Chief of Army Staff. His piety, patriotism and professionalism turned himapolitical solider and successful coup-maker in the circumstances of the 1977 PNA agitation.The opposition paralyzed governmentwith agitation movement.This situation provided another opportunity for military to takeover. General Zia ulHaqcame in power on July 5, 1977 peacefully.(Ahmad P. G., 1988)

Appointment of Zia-ul-Haq had been contentious. He was junior to several other generals and had no eminent service record. General Zia ulHaq created a civilian frontage through party-less elections in 1985. In this situation he ruled country for next eleven years. This came to be commonly known as Operation Fair play. General Zia-ul-Haq projected himself as a reluctant ruler. He argued quite emphatically that armed forces had to step into political field.The situation was quite clearabout political crises. It was assumed that politicians were unable to resolve crisis. He emphasized in no uncertain terms, like the preceding military rulers, that neither he nor his colleagues had any political ambition or agenda. He promisedto return country back on democratic system in 90 days. (Bajwa, 1999)

General Zia-ul-Haq declared, "My sole aim is to organize free and fair elections which would be held in October this year 1977. Soon after the polls, power will be transferred to the elected representatives of the people. I give a solemn assurance that I will not deviate from this schedule. During the next three months my total attention will be concentrated on the holding of elections and I would not like to dissipate my powers and energies as Chief 
Martial Law Administrative on anything else”. In other statement General Zia-ul-Haq said, "I will not accept a political office because I do not think I am fit for that." He also explained about situation of constitution. The constitution had not been annulled. It was temporarily suspended. However Zia instead of keeping his promise of holding elections in 90 days, embarked on an unending and equally convoluted process of accountability. He thought it rather more important to hold local bodies elections in 1979 and then in 1983 general election in Pakistan.(Rizivi, 2000)

\section{The Referendum of Zia-ul-Haq}

General Zia-ul-Haqdismissed Prime Minister Z.A. Bhuttoon July 5, 1977 and Chief Martial Law Administrator of Pakistan andestablished a military government. (Syed, 1996)Prime Minister with his cabinet was arrested under protective custody. However President of Pakistan ChaudaryFazalElahi was allowed to continue. He was acting as Titular Head of State till retirement on September 1978. After the completion of the period then General Zia-ul-Haq, assumed office of President of Pakistan and continued till his death. (Shahab, 1989)It was also political tactics of electoral politics in Pakistan which were opted with-out some pattern of election with Electoral College. Chairman of P.P.P.former Prime Minister of Pakistan Z.A.Bhutto was hanged in 1979.The elections were once again adjourned for unspecified period. Theadjourning of election was exclusivelyaltered political scenario. This predominantgovernmentalconditionobligated P.P.P and some parties of PNA to formulate coalition forrefurbishment of democratic system in Pakistan. The political parties coalition sponsored a four point program; theculmination of martial law, restoration of constitution 1973, parliamentary elections and transfer of power to public representatives.(Feldman., 1975)M.R.D instigated a movement in 1983. First time it was feltperil to government. There wasinsurrection in Sindh againstautocratic and dictatorial rule. Christina Lamb wrote "The greatest threat to Zia came in 1983, when the PPPled the Movement for Restoration of Democracy (MRD) launched a Movement to topple him. The Movement was crushed by the use of brutal force of the army. Zia was afraid from the re-uprising of the movement. He was trying to find out way to prolong his rule in this connection a referendum held in 1984 but majority of people of Pakistan rejected it on the appeal of MRD. Some analysis put the turnout as low as $2 \%$ per cent. But Zia took it as a vote of confidence in himself anyway." (Lamb, 1991)

The political pressure of opposition parties was on rise in movement re-establishment of democracy. General Zia decided to institute a pseudo-democracy in Pakistan.He wanted to be electedas President under a civilian setup. For this purpose, he decided to get support from people of Pakistan for endorsement of his policies. It was being done in form of a referendumin August 1983. The constitution does provide opportunity for referendums atnational issue. The articles in support of referendum are as follow; "Article 48, (6) If, at any time, the President, in his discretion, or on the advice of the Prime Minister, considers that it is desirable that any matter of national importance should be referred to a referendum, the President may cause the matter to be referred to a referendum in the form of a question that is capable of being answered either by Yes or No.(7) An act of Majlis-e-Shoora (Parliament) may lay down the procedure for holding of a referendum and compiling and consolidation of 
the result of a referendum.”(Constitution, 1973)

In constitution of 1973 were made Constitutional Amendments as the Seventh Amendmentwas made for the perspective of referendum.(Pakistan Constitution)"Article 2, insertion of new article 96-A, in constitution.In Constitution of Islamic Republic of Pakistan, hereinafter referred to as Constitution, after Article 96, the following new Article shall be inserted, namely, "96-A: Referendum as to confidence in Prime Minister (1) If at any time the Prime Minister considers it necessary to obtain a vote of confidence of the people of Pakistan through a referendum, he may advise the President to cause matter to be referred to a referendum in accordance with law made by Parliament. (2) The law referred to in clause (1) shall provide for Constitution of Referendum Commission and the manner and mode of holding a referendum. (3) On receipt of the advice of the Prime Minister under clause (1) President shall call upon the Referendum Commission to conduct a referendum amongst the persons whose names appear in electoral rolls for the immediately preceding general elections to the National Assembly as revised up-to-date.(4) Any dispute arising in connection with the counting of votes at referendum shall be finally determined by the Referendum Commission or a member there of authorized by it and, save as aforesaid, no dispute arising in connection with a referendum or the result thereof shall be raised or permitted to be raised before any court or other authority whatsoever. (5) If, on the final count of the votes cast at the referendum, the Prime Minister fails to secure majority of the total votes cast in the matter of the confidence of the people of Pakistan, he shall be deemed to have tendered his resignation with-in the meaning of Article 94."(Pakistan Constitution)

Under the umbrella of constitution,General Mohammed Zia-ul-Haq issued referendum order 1984. The assorted question was asked to voters in Pakistan. "Do you endorse the process initiated by General Mohammed Zia-ul-Haq, President of Pakistan, for bringing the laws of Pakistan in conformity with the injunctions of Islam as laid down in the Holy Quran and Sunnah of the Holy Prophet (peace be upon him), and for the preservation of the Islamic ideology of Pakistan, the continuation and consolidation of that process, and for smooth and orderly transfer of power to the elected representatives of the people." Referendum was held on December 19, 1984. It was aneffort to seek legitimacy withendorsementof peoplefor policy of Islamizationoriginated by General Zia. The vote in positive inreferendum would meana term as President of Pakistan for five years. It was claimed by General Zia. General Election was held on February 1985. The Martial Law was lifted on the December30, 1985. After the implementation of $8^{\text {th }}$ amendment Zia became the strong President in the weak political institutions.(Ali, 1983)

MRD decided to boycott referendum. The result of referendum was predictable. Therecasting rate of voteswas 62.16percent. The ratio of votes casted in favor of policies was about 98.53 percent in which people polled affirmative to backingpresent government policies. The majority of parties defiedendorsed results of ballot. Opposition leaders of different parties claimed that about actual turnout rate of voting was less than five percent. General Zia overruled claim by declaring he won public endowmentto continue as President of Pakistan for next term of five years.(Kamran, 2008) 
The referendum provided legitimacy to Chief Martial Law Administrator General Muhammad Zia-ul-Haq to perform President. When he assumed as President General Zia broadcastedfor elections of National and Provincial Assemblies in February 1985. These elections would be conducted on a non-party basis. (http://ghazali.net/book1/Chapter8a/body_page_2.html; http://c2d.unige.ch)

\section{General Elections of 1985}

The general elections held on February 25,1985 in which number of registered electors was 32589996 . Voters used right to vote for selection of representative candidates were 17250482 and the casting rate was 52.93 percent.The elections were fortwo-house parliament which comprises of National Assembly and Senate. The Lower House consisted of 237 members. These members were chosen for period of five years. Twenty one seats were reservedfor women who were nominatedand nine for non-Muslim reserved for representation. The Upper Housewas consisted of eighty seven members. There were fourteen general members designated by each provincial assembly. Five senators were elected by each of provincial assembly to represent Ulemas,technocrats and other professionals. There were eight members elected fromFederally Administered Tribal Areas by National Assembly members. Three senators were chosen forrepresentation of Islamabad. Term of senators is six years. The half of strength of senators was retiredafter threeyear. Prime Minister Mohammad Khan Junejowith new Cabinet took oath on April 10. The elections were not contested on political issues. The candidates had not proper agenda of these elections. General elections of 1985 were held non-party basis which had notpositive impacts onpolitical culture for participation in democratic process. The elections campaign was based onbrothery as well as local issues. Non democratic and non-party base elections were caused of ethnic and sectarian issues. During 1980s such issues developed in politics of country. The clan, sect, tribe, and ethnicity wereimportant factoring of electioncampaign for voters as political issues of electoral contesting candidates.(Omar, 1988)The most significant consequence of non-party election inevitable gyrated around tribal, ethnic and sectarian issues instead political program.(Tahir, 1993)

The non-party elected governmentclaimed electionswere good determination for thedevelopment for Islamization. It could be possible with sufficientparticipation of people. It was observed during inelections campaign that majority candidates had no national or international issues. Those were debatingabout local issues. The candidates convinced people for their support on personal, ethnic and tribal relations. The interpretations about theseelections which had primarily concerned on local issues and seldom made debates on national issues as trade, Islam, democracy, martial law, economy and foreign affairs were not part of electioneering. These elections performed in reducing national politics to municipal level. Mostintellectuals and social scientist are agreed that non-party elections have reverse democratic impact on politics of country especially on politics of Sindh province. The impact of non-party elections wasthat ethnic politics increased and many ethnic groups became more powerful. MQM, P.P.I, Pukhtoon federation, were the result of such elections. (Akhtar, 2000) 


\section{Electoral System}

Pakistani citizenshaving age of 21 years (now 18 years) were registered as voters. The insane were notpermitted to vote in constituency residence. At district levelElectoral registers were revised. The Voters have no compulsion for voting. The candidatesfor National Assemblyshould be 25 years which werequalified to contest election. To qualify for contest the election of Senate is 30 years age. These persons were debarred to contest election house of parliament which is penalized to imprisonment for a term which was not less than two years. The individuals have been terminated,detached or forcibly retired from service. All persons were excluded from both houses which were discharged bankrupts, or public office bearers cannot concurrently be members of parliament. The seats are allocated on basis of population for lower houses of parliament for representation of each province,FATA and Federal Capital. On theprinciple of simply majority members of assemblies were elected in single member constituency. According toproportional representation seats of Senate allocated to each province.Elections were held to fill parliamentary seats which fall vacant between general elections. (A Report on The 1985 Partyless Election Pakistan, 1988) The democratic process started from lowest level to provide stuff for political system. Urbanization and education has also a role in the political development of electoral process.As a result many municipal bodies councilors from local level politics to the national and provincial assemblies.(Cheema, 2003)

Table No 5

\section{Background of National Assembly Members 1985}

\begin{tabular}{|l|l|}
\hline Tribal Leaders and Landlords & 157 \\
\hline Urban Professionals & 18 \\
\hline Religious Leaders & 06 \\
\hline Businessmen & \\
\hline
\end{tabular}

Source;(Norman, p.127)

The results showed political parties became weak due to non-party election. Different classes emerged in political system of Pakistan. These groups griped over political institutions. This elite class did not belong to political parties. Authoritarian regime formed King's party to rule over country. There were seats of National assembly distribution as following as,

Table No 6

\section{National Assembly Distribution of Seats}




\begin{tabular}{|l|l|l|l|l|l|}
\hline Region & Muslim & Women & Christian & Hindu & Buddhist \\
\hline Punjab & 115 & 12 & 04 & & - \\
\hline Sind & 46 & 04 & - & 04 & - \\
\hline N.W.F.P & 26 & 02 & - & - & - \\
\hline Baluchistan & 11 & 02 & - & 02 & - \\
\hline FATA & 8 & - & - & - & - \\
\hline Islamabad & 1 & 0 & - & - & - \\
\hline Total & 207 & 20 & 04 & 06 & \\
\hline
\end{tabular}

(Politics without Parties, A Report on the 1985 Party less Election Pakistan, 1988.p.11,12-15)

In Pakistan general election of 1985 was held on principle of separate electorate. The small ethnic groups got suitable representations at national level as well as provincial level.Constitutional it was made efforts to balance representation of minorities in parliament. There a right was admitted in Objective Resolution as well as in constitution.There was representation of general seats as well as women with minorities at provincial level in all federal units as follow as,

Table No 6

\section{Provincial Assemblies Distribution of Seats}

\begin{tabular}{|l|l|l|l|l|}
\hline Province & Muslim & Women & Minorities & Total \\
\hline Baluchistan & 40 & 2 & 3 & 45 \\
\hline N.W. F. P & 80 & 4 & 3 & 87 \\
\hline Sind & 100 & 5 & 9 & 114 \\
\hline Punjab & 240 & 12 & 8 & 260 \\
\hline Total & 460 & 23 & 23 & 506 \\
\hline
\end{tabular}


( Election Commission of Pakistan)

The division of seats according to constitution province wise mentioned above. The general seats for members of Provincial Assemblies were formatted keeping ratio of population. Punjab had maximum population in Pakistan. The number of seats for members of Provincial Assembly was also more than other provinces of Pakistan. Sind province was at second number for strength of member of provincial assembly.

Table No 7

\section{Voters in Each Province}

\begin{tabular}{|l|l|l|l|}
\hline Province Voters & Population & N.A Seats & Voters \\
\hline Punjab & 47,292441 & 115 & 21125289 \\
\hline Sind & 19,028666 & 46 & 7652825 \\
\hline NWFP & 11,061328 & 26 & 4173930 \\
\hline Baluchistan & 4,332376 & 11 & 1409143 \\
\hline FATA & 2198547 & 8 & 30583 \\
\hline Islamabad & 340,286 & 1 & 149,176 \\
\hline
\end{tabular}

(Politics without Parties, A Report on the 1985 Party less Election Pakistan, 1988.p.11,12-15)p. 22

This general election was held on basis of adult franchise and voters used their right for choice of their representatives. The data showed voters of Punjab casted votes for selection of representative is comparatively good than other provinces. After long period of martial law, people participated in governing issues for establishment of democratic system in Pakistan.In the election of 1985 voters turn-out was as following as,

Table No 8

The 1985 General Elections: Voters' Turn-out

\begin{tabular}{|l|l|}
\hline National Assembly & $52.93 \%$ \\
\hline Punjab & $61.80 \%$ \\
\hline
\end{tabular}




\begin{tabular}{|l|l|}
\hline Sind & $49.82 \%$ \\
\hline NWFP & $47.61 \%$ \\
\hline Baluchistan & $46.62 \%$ \\
\hline
\end{tabular}

Source; Election Commission of Pakistan

The election 1985 held on non-party basis after long period of martial law. The people took interest in political system of Pakistan for development of democratic process. Public participation was requisite for establishment of democratic process in Pakistan. The results showed positive sign of public participation.

\section{Conclusion}

Democracy is modern notation of state governance with mass participation and representation. Democratic system is based on electoral process for the selection of representative for decision making.The independent institutions are requisite of modern democratic state. The civil and military elites decided to control state governance system with the alliance of weak political leaders. The factors affecting the parliamentary democracy are good governance, fluid political structure and power politics. The prominent and well known landlord families from the provinces of Punjab, Sind, KPK and the tribal chiefs of Baluchistan established their hold over the elected bodies of political system of Pakistan. The long period of martial law imposed restrictions on political parties and mass mobilization which enabled feudal elite to emerge triumphant in the polls. Under the cover of martial law sectarian and biradari differences rose in politics of Pakistan. In election of 1985 candidates tried to get support on the basis of different prejudices.

It has been studied that the transparent and free elections are foundation of modern democracy. The elections should be held after specific period of time. It is source of change of government quietly and peacefully. In Pakistan the efforts are made for independent and autonomous election commission. There is no scientific system to block loan defaulters to contest election. The election contesting candidates in Pakistanare not securitized properly. The prerogative objectivesof elections are to legitimate the unconstitutional rulersin Pakistan. The martial law has need of legitimacy from the parliament. The democratic institutions are still not matured after long travel of sixty six years. The civilian transform of one regime to other not happened in normal manner.

Theoscillation of Judiciary provides support for military intervention and legitimacy of unconstitutional regimes having impacts on electoral politics. Political horse trading, lack of visionary political leadership and issues of corruptions in governance lessenedthe public participation in the governing issues. The institutional improvement is enacted with constitutional development which remains in crisis in Pakistan. The constitution formulates boundaries of state organs as executive, parliament and judiciary. Pakistan is facing 


\section{Macrothink}

problems to maintain these democratic ideals in the society.The constitution is formulated for public aspiration. The constitutional amendments were distorted the politicalsystem in Pakistan. There are painful stories of corruption and misuse of power ingovernment. The bothering of political leaders for the welfare of public with effective legislation enhances the costing rate for voting. The factors such as public awareness, enthusiasm of the opposition, popular organizations and determinants of the circulation of powersare affectingelectoral politics for democratic process.

\section{Bibliography}

(n.d.). Election Commission of Pakistan. ; Election Commission of Pakistan .

(1988). A Report on The 1985 Partyless Election Pakistan. Society For the Advancement of Education (SAHE).

A.V.Vorys. (1956). Political Development in Pakistan. New Jursy: Princeton University.

Ahmad, K. (May 23, 1998). Khaled Ahmed (May 23, 1998). The secular Mussalman. . Dheli: The Indian Express. http://www.indianexpress.com/res/web/pIe/ie/daily/19980523/14350814.html. .

Ahmad, M. (1959 p.106). Politics and Government. Karachi: Royal Book Company.

Ahmad, M. (1959 p.89). Politics and Government. Karachi, Pakistan: Royal Book Company. Ahmad, P. G. (1988). Phir Marshal Law Aa Gaya. Lahore: Jang Publisher.

Ahmad, Q.-u.-D. (1979). Pakistan Facts and Fallacies. Karachi: Poyal Book Publisher 
Company.

Akhtar, R. S. (2000). Medina, Religion and Politics in Pakistan. Karachi: Oxford University press.

Ali, C. M. (1983). Emergence of Pakistan. Research Society of Pakistan: University of Punjab.

Bajwa, F. (1999). Pakistan a Historical and Contemporary Look. Karachi: Oxford University Press.

Bhutto, Z. A. (1971). The Great Tradegy. Karachi: Pakistan People Party.

Bukhari, A. H. (1964). Constitutional History of Indo Pakistan. Lahore: Muhammad Suliman Qureshi and Sons.

Charles, K. (2005). Constitutional and Political Change in Pakistan: The Military Governance Paradigm. Propsect for Peace in South Asia. Standford University.

Chaudhary, G. (1963). Democracy in Pakaistan. Dacca: Green Book House.

Cheema, A. (2003). State and Capital in Pakistan: The Changing Politics of Accumulation. In A.M., Corporate Capitalism in Contemporary South Asia: Conventional Wisdoms and South Asian Realities,. New York: Palgrave.

Constitution. (1973). $\quad$ Retrieved 2014, from http://www.pakistani.org/pakistan/constitution/part3.ch1.html.

Dominque, L. a. (1975). Freedom at Midnight. Great Britian: Harper Collins Publisher.

Feldman, H. (1975). A Constitution for Pakistan. London: Oxford University Press.

Feldman, H. (1975). A Constitution for Pakistan. London: Oxford University Press.

Feldman, H. (1975). The End and The Begining: Pakistan 1969-1971. London: Oxford University Press.

Feldman, H. (1975). The End and The Begining: Pakistan 1969-1971. Landon: Oxford University Pres.

Feldman., H. (1975). A Constitution for Pakistan, London: Oxford University Press. London: Oxford University Press.

G.W.Chaudary. (1969 p.67). Constitutional Development in Pakistan. London: Low and Brydone Printers Ltd.

Ghaur, A. (1993). Ayub Khan, Pakistan First Military ruler. Lahore: Sange-e-Meel.

Ghaur, A. (1994). In Ayub Khan: Pakistan's First Military Rule. Lahore: Sang-e-Meel.

Gopal, R. (1959). Indian Muslims: A Political History. Bomby: Asia Publishing House.

Hamid, K. (2001 Pp 136-143). Constitutional and Political History of Pakistan. Karach: 
Oxford University Press.

Hamid, K. (2006). Constitutional and apolitical History of Pakistan, . Karachi: Oxford University Press.

Herbert, F. (1972). From Crisis To Crisis, Pakistan 1962-1969. London: Oxford University Press.

Herlad. (2002). Source Herlad Election Guide / October 2002. p.38.

http://ghazali.net/book1/Chapter8a/body_page_2.html; http://c2d.unige.ch. (n.d.). Retrieved from http://www.storyofpakistan.com/articletext.asp?artid=A076.

K.K.Aziz. (1976). Party Politics in Pakistan 1947-1958. Lahore: Sange-e-Meel.

Kalam, M. A. (1959). India Wins Freedom. Calcutta: Orient Longman.

Kamran, D. T. (2008). Democracy and Governance in Pakistan. Lahore: South Asia Partnership.

Keesing. (1973). Pakistan 1947 to the Creation of Bangladesh. New York: Charles Scribner's Son.

Khan, H. (2001). Constitutional and Political History of Pakistan. Karachi: Oxford university Press.

Khan, H. (2006). Constitutional and Political History of Pakistan. Karachi: Oxford University Press.

Lamb, C. (1991). Waiting for Allah, Pakistan's struggle for Democracy. New Dheli: Viking Penguin Book.

Mujahid, S. a. (1980). The 1977 Pakistani Elections: An Analysis . In M.-u.-D. Ahmad, Contemporary Pakistan: Politics, Economy and Society (pp. 63-91). Durham: North Carolina: Academic Press.

Norman, O. (p.127). Pakistan A Political and Economic History since 1947. p.127. Karachi: Dawn.

Omar, N. (1988). The Political Ecconomy of Pakistan. London: KPI.

Omer Norman. ( p.127). Pakistan A Political and Economic History since 1947.

(n.d.).

Pakistan

Constitution.

http://www.pakistani.org/pakistan/constitution/amendments/7amendment.html.

Rashid, A. (2001). In Taliban: Militant Isam, Oil and Fundamentalism in Central Asia. New Haven, USA: Yale University.

Report. (1988.p.11,12-15). Politics without Parties, A Report on the 1985 Party less Election Pakistan. Lahore: Society for the advancement of Education (SAHE).

Rizivi, H. A. (2000). The Military and Politics in Pakistan 1947-1997. Lahore: Sange-e-Meel 
Publication.

Shahab, R. U. (1989). Gensis of Pakistan. Lahore: Takhleeq Markaz.

Syed, A. H. (1996). Discourses of Politics. New Dehli: Deep \& Deep Publication.

Tahir, A. (1993). Ethno National Movements of Pakistan Domestic and International Factors. Islamabad: Institute of Policy Studies.

Weinlaum, M. (July 1977). The March 1977 Election. Asian Survey No 7.

Ziring, L. (1997). Pakistan in The Twentieth Century. Karachi: Oxford University Press. 